Asian J. Med. Biol. Res. 2017, 3 (4), 494-498; doi: 10.3329/ajmbr.v3i4.35340

\author{
Asian Journal of \\ Medical and Biological Research \\ ISSN 2411-4472 (Print) 2412-5571 (Online) \\ www.ebupress.com/journal/ajmbr
}

\title{
Article \\ Toxic effects of agro-pesticide cypermethrin on histological changes of kidney in Tengra, Mystus tengara
}

\author{
Shahroz Mahean Haque, Chayan Chandra Sarkar, Sabiha Khatun* and Kaizar Ahmed Sumon \\ Department of Fisheries Management, Faculty of Fisheries, Bangladesh Agricultural University, Mymensingh- \\ 2202, Bangladesh \\ *Corresponding author: Sabiha Khatun, Department of Fisheries Management, Faculty of Fisheries, Bangladesh \\ Agricultural University, Mymensingh-2202, Bangladesh. Phone: +8801760236402; E-mail: \\ sabihasathy22@gmail.com
}

Received: 07 December 2017/Accepted: 20 December 2017/ Published: 28 December 2017

\begin{abstract}
Cypermethrin, the synthetic pyrethroid commonly used as a pesticide, contaminates the aquatic ecosystem as a toxic pollutant from agricultural and domestic washouts. An experiment was conducted to carry out an empirical study to investigate the sub-lethal effects of $\mathrm{LC}_{50}$ value of a pyrethroid pesticide, cypermethrin $10 \mathrm{EC}$ on histological changes of kidney in Tengra, Mystus tengara at wet laboratory of the Faculty of Fisheries, Bangladesh Agricultural University (BAU), Mymensingh. The $\mathrm{LC}_{50}$ value of cypermethrin $10 \mathrm{EC}$ was calculated by probit analysis and $\mathrm{LC}_{50}$ value for 96 hours was found $0.133 \mathrm{ppm}$. The experiment was conducted with four treatments, each with three replications. Treatment one (T1) was used as control (0 ppm) and three concentrations, such as $0.026 \mathrm{ppm}\left(20 \%\right.$ of $\left.96 \mathrm{~h} \mathrm{LC}_{50}\right), 0.052 \mathrm{ppm}\left(40 \%\right.$ of $\left.96 \mathrm{~h} \mathrm{LC}_{50}\right)$ and $0.104 \mathrm{ppm}(80 \%$ of $96 \mathrm{~h} \mathrm{LC}_{50}$ ) were used as Treatment two (T2), Treatment three (T3) and Treatment four (T4), respectively. For histological study kidney of studied fish were collected from control and experimental group at 7, 14 and 28 days interval up to the end of experiment of 28 days. The physical reactions observed in the treated fish were erratic swimming, discolorations of the skin, loss of reflex, hyperactivities, motionless state and these effects increased with increasing concentration of the toxicants and duration of exposure. The changes observed in the kidney tissues were vacuolation, necrosis, ruptured kidney tubules, Cellular degeneration and karyolysis were recorded. Cypermethrin $10 \mathrm{EC}$ has adverse effects on the organs of fish, so it should not be used indiscriminately in agriculture and aquaculture.
\end{abstract}

Keywords: histology; cypermethrin; Mystus tengara; toxicity; $\mathrm{LC}_{50}$

\section{Introduction}

Bangladesh is an agricultural country where more than $80 \%$ of the people depend on agriculture for their living. With the growing demand for food, use of chemicals like fertilizer and pesticides in agricultural land has increased since 1954. Constant use of pesticides in crop fields has led to decreased biodiversity of fauna. Pesticides in aquatic ecosystem have become a matter of concern because of their toxicity and tendency to accumulate in food chain.

Fishes live in the aquatic column; they are facing challenge for surviving from pollutants, particularly from various chemical fertilizers and pesticides used in or adjacent paddy fields or flood lands. Pesticides reach aquatic ecosystems by direct application, spray drift, aerial spraying, erosion and run off from agriculture land. These huge amounts of pesticides may get deposited in the flood lands and other open water wetlands and rivers of the country (Plimer 1988; Miskiewicz and Gibbs, 1994).

In Bangladesh, more than 300 types of pesticides and insecticides are used for crop protection in agriculture. Over $98 \%$ of sprayed insecticides and $95 \%$ of herbicides reach a destination other than their target species, including non-target species, air, water, bottom sediments, and food. 
Cypermethrin is a broad-spectrum insecticide easily degraded on soil and plants. Cypermethrin is highly toxic to fish and aquatic invertebrates (Asztalos et al., 1990), in an ecosystem, intricate relationships exist between the organisms and their surroundings, exposure of an ecosystem to such toxicant may result in loss of species diversity, which is an important characteristic of healthy ecosystems.

Mystus tengara, commonly known tengra is a freshwater catfish species of family Bagridae under the order Siluriformes. It used to inhabit in both flowing and standing waters of rivers, ponds, inundated fields and derelict water bodies.Fish are often used as indicators of such biological impacts of pollutants as they respond to low concentrations of toxic substances (Ayas et al., 2007). Alteration in the histology of the tissue such as gill, liver, kidney or intestine that are directly related to the contaminants serve as important bio-monitoring tools or bio-markers to assess the toxicity (Thophona et al., 2003). . In the present study, an attempt was made to examine the sub-lethal toxic effects of different concentrations of cypermethrin $10 \mathrm{EC}$ on the kidney of the test fish, M. tenara and as well determine the $96 \mathrm{~h} \mathrm{LC}_{50}$ of the $M$. tengara exposed to the toxicant.

\section{Materials and Methods}

\subsection{Study area and Collection of experimental fish}

The experiment was carried out in the Wet laboratory of the Faculty of Fisheries, Bangladesh Agricultural University (BAU), Mymensingh. The healthy and pre-adult of the M. tengara (weight $7.86 \pm 1.72 \mathrm{~g}$, length $8.24 \pm 0.77 \mathrm{~cm}$ ) were collected from the local dealer of Mymensingh and allowed to acclimatize to the laboratory conditions for 21 days to remove the suspected unhealthy subjects at $22 \pm 0.5^{\circ} \mathrm{C}$ before the experiment. During acclimatization period, fishes were fed with artificial pellet feed and water of the plastic drum was also changed once daily. Feeding was stopped $24 \mathrm{~h}$ prior to the commencement of the toxicity test experiment.

\subsection{Pesticide selection and collection}

Cypermethrin $10 \mathrm{EC}$ was collected from Mymensingh town. The commercial grade cypermethrin $10 \mathrm{EC}$ was measured by a micropipette (Model E-MILB5700, England). The stock solution was prepared according to EC\% active ingredient and desired concentrations of pesticides were poured carefully into 100L of tap water in the test plastic drums by a micropipette and gently stirred with a glass rod to ensure complete mixing.

\subsection{Experimental procedure}

Before starting the test, all experimental plastic drum were cleaned and filled with $100 \mathrm{~L}$ tap water. Then 10 fish were transferred into each drum. Six different concentrations $(0.1,0.2,0.4,0.8,1.6$ and $3.2 \mathrm{ppm})$ of cypermethrin with control units $(0 \mathrm{ppm})$ were used in the test series to determine the 96 hours lethal concentration values $\left(\mathrm{LC}_{50}\right)$ of cypermethrin $10 \mathrm{EC}$. Several behavioral changes were observed during the exposure period. The $\mathrm{LC}_{50}$ of cypermethrin $10 \mathrm{EC}$ on the test fish was determined using probit analysis.

\subsection{Experimental design for measurement of kidney histology}

The experiment was conducted with four treatments, each with three replications. Treatment one $\left(\mathrm{T}_{1}\right)$ was used as control $(0 \mathrm{ppm})$ and three concentrations, such as $0.026 \mathrm{ppm}, 0.052 \mathrm{ppm}$ and $0.104 \mathrm{ppm}$ were used as treatment two $\left(\mathrm{T}_{2}\right)$, treatment three $\left(\mathrm{T}_{3}\right)$ and treatment four $\left(\mathrm{T}_{4}\right)$, respectively. Ten fish were transferred in each drum. Water and pesticide were renewed at every $24 \mathrm{~h}$. Kidney were collected an interval of 7, 14 and 28 days. Then immediately taken in vials filled with $10 \%$ formalin. Preserved tissues were washed under tap water for 24 $\mathrm{h}$ to remove formalin, dehydrated, clarified with xylene and embedded in paraffin blocks. They were cut at $4-5 \mu$ thickness by using microtome machine and stained routinely with haematoxylin and eosin (H\&E) for histological examination. Stained sections were examined under trinoculare microscope.

\section{Results}

\subsection{Acute toxicity of cypermethrin $10 \mathrm{EC}$ and mortality percentages of test fish}

Fish were observed to show erratic swimming, loss of reflex, hyperactivities, motionless state and discolouration and these effects increased with increasing concentration of the toxicants and duration of exposure. However, the control group fish (only tap water) was found to be normal behavior during the experimental period.

Table 1 shows the mortality patterns in relation to cypermethrin dosage. No mortality was taken place in control samples. Mortality percentages were increased with increasing concentrations of cypermethrin $10 \mathrm{EC}$ and time intervals (Table 1). The $\mathrm{LC}_{50}$ value was calculated by probit analysis. The probit analysis showed that the lethal concentration for $50 \%$ mortality of the fishes at 96 hours was $0.133 \mathrm{ppm}$. 
Table 1. Mortality percentages of the selected fish samples exposed to different concentrations of cypermethrin $10 \mathrm{EC}$ at different time intervals.

\begin{tabular}{lllllll}
\hline $\begin{array}{lllll}\text { Concentration } \\
(\mathbf{p p m})\end{array}$ & Initial count of fish & \multicolumn{3}{c}{$\begin{array}{c}\text { Number of dead fish at different } \\
\text { exposure time (hours) }\end{array}$} & Mortality (\%) \\
\cline { 2 - 5 } & & $\mathbf{2 4}$ & $\mathbf{4 8}$ & $\mathbf{7 2}$ & $\mathbf{9 6}$ & \\
\hline 0.0 (control) & 10 & - & - & - & - & 00 \\
0.1 & 10 & 2 & - & - & - & 20 \\
0.2 & 10 & 4 & 5 & & & 90 \\
0.4 & 10 & 10 & - & - & - & 100 \\
0.8 & 10 & 6 & 4 & - & - & 100 \\
1.6 & 10 & 6 & 4 & - & - & 100 \\
3.2 & 10 & 5 & 5 & - & - & 100 \\
\hline
\end{tabular}
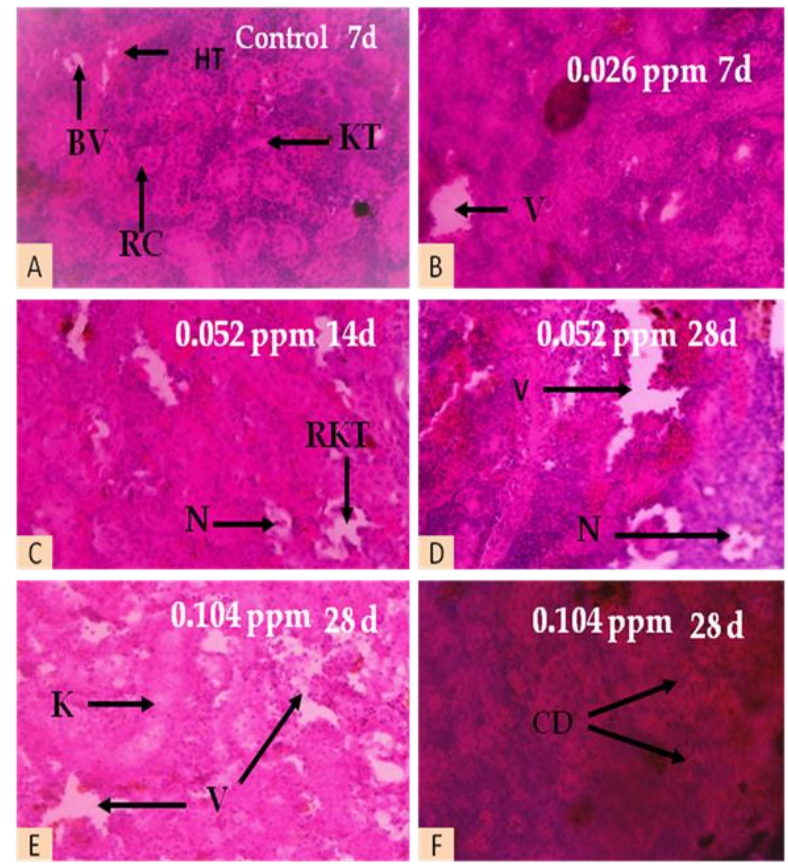

Figure 1. Histological changes in kidney (H and E stained, X100) exposed to cypermethrin $10 \mathrm{EC}(\mathrm{E})$ Control (T1); (F) $0.026 \mathrm{ppm}$ (T2); (G) $0.052 \mathrm{ppm}$ (T3); (H) $0.104 \mathrm{ppm}$ (T4) at 14 days of exposure. Arrowheads are indicating Blood Vessel (BV), Hematopoeitic Tissue (HT), Kidney Tubules (KT), Renal Corpuscle (RC), Necrosis (N), Ruptured Kidney Tubules (RKT), Karyolysis (K) and Cellular Degeneration $(\mathrm{CD})$.

\subsection{Histological alteration in kidney}

Kidney tubules and hematopoietic cells were normal and systematically arranged in the control treatment (Figure 1.A). Kidney tissue from M. tengara exposed to $0.026 \mathrm{ppm}$ showed vacuolation (Figure 1.B) at 7 days. Necrosis, ruptured kidney tubules (Figure 1.C) and diffused vacuolation (Figure 1.D) were found at the doses of $0.052 \mathrm{ppm}$ of 14 and 28 days exposed fish. Vacuolation, karyolysis (Figure 1.E) and Cellular degeneration (Figure 1.F) were also recorded at the higher dosage of $0.104 \mathrm{ppm}$ at 28 days exposed fish.

\section{Discussion}

\subsection{Acute and behavioral toxicity of cypermethrin 10EC}

Freshwater fishes are critical as a protein-rich food source but they are also susceptible to the acute and chronic presence of pollutants (Thingran, 1974). Cypermethrin are commonly used in agriculture sector that continuously pollute the inland fishery water. In the present study the $\mathrm{LC}_{50}$ value of cypermrthrin $10 \mathrm{EC}$ was found $0.133 \mathrm{ppm}$ in $M$. tengara. This result indicated that the fish was unable to withstand the exposure of cypermethrin $10 \mathrm{EC}$ with time and thereby the toxicity of the insecticide was possible on long exposure. In an experiment it was found that the $\mathrm{LC}_{50}$ value of cypermethrin was $0.063 \mathrm{mg} / \mathrm{l}$ to juvenile African catfish, $C$. 
gariepinus for 96h of exposure (Ayoola and Ajani, 2008). Monir et al. (2015) reported that the LC50 value of cypermethrin to Pangasianodon hypophthalmus was $0.075 \mathrm{ml} / \mathrm{L}$ over an exposure period of 96 hours.

\subsection{Histological alterational of Kidney}

Histological analysis appears to be a very sensitive parameter and crucial in determining cellular changes that may occur in target organs, such as liver and kidney (Dutta, 1996). Histology may prove to be a cost effective tool to determine the health of fish populations, therefore reflecting the health of an entire aquatic ecosystem in the bio-monitoring process.

The kidney of the treated fish compared to the control showed vacuolation, necrosis, ruptured kidney tubules, karyolysis and cellular degeneration. Furthermore, similar findings also have been reported in Heterobranchus bidorsalis exposed to different doses of cypermethrin (Olufayo and Alade, 2012), in Labeo rohita exposed to organochlorine pesticide endosulfan (Indirabai et al., 2010), in Silver barb (Barbonymus gonionotus) exposed to an organophosphorous pesticide Quinalphos 25 EC (Mostakim et al., 2014), in Nile tilapia (Oreochromis niloticus) exposed to an organophosphorous pesticide Kinalux 25 EC (Nannu, 2014), in Cirrhinus mrigala expose to lethal $(5.13 \mu \mathrm{g} / \mathrm{l})$ and sublethal $(1.026 \mu \mathrm{g} / \mathrm{l})$ to pyrethroid derivative cypermethrin (Prashanth, 2011). Butchiram et al. (2009) studied on histopathological changes in the gill, liver and kidney of Channa punctatus exposed to alachlor for a period of 10 days. They observed changes in the kidney include: necrosis, swelling of renal tubules, cellular hypertrophy and granular cytoplasm which are also differ with the present study.

From the above discussion we can say that cypermethrin $10 \mathrm{EC}$ is sigficantly toxic to the Mystus tengara. The little amount of this pesticide can causes histological changes in liver and kidney of tengra and finally death of fishes.

\section{Conclusions}

The freshwater catfish, M. tengara exposed to various concentration of cypermethrin 10 EC resulted that this synthetic pyrethroid was highly toxic with lethal concentration $\left(\mathrm{LC}_{50}\right)$ of $0.133 \mathrm{ppm}$. The present histpathological investigation demonstrates a direct correlation between cypermethrin exposure and histoarchitecture changes observed in kidney. The data from this study will enhance our understanding of ecosystems and organism health, which can then be conveyed to local people and communities to effective manage and thus decrease the use of pesticides, herbicides, and other contaminants. Therefore, cypermethrin 10 $\mathrm{EC}$ which are used in aquaculture as treatment and disinfectant should be used very carefully.

\section{Acknowledgements}

The author acknowledges the financial support by the AquaFish Innovation Lab of United States Agency for International Development (USAID).

\section{Conflict of interest}

None to declare.

\section{References}

Asztalos B, J Nemcsok, I Benedeczky, R Gabriel, A Szabo and OJ Refaie, 1990. The effects of pesticide on some biochemical parameters of Carp (Cyprinus carpio L.). Arch. Environ. Contam. Toxicol., 19:275- 282.

Ayas Z, G Ekmekci, M Ozmen and SV Yerli, 2007. Histopathological changes in the livers and kidneys of fish in Sariyer Reservoir. Turkey Environmental Toxicology and Pharmacology, 23: 242-249.

Thophona, M Kruatrachuea, ES Upathama, P Pokethitiyooka, S Sahaphongb and S Jaritkhuanc, 2003. Histopathological alterations of white seabass, Latescalcarifer in acute and subchronic cadmium exposure. Environ. Pollut., 121: 307-320.

Plimer JR, 1988. Movement of pesticide from the site of application. IAEA SM-297/35, in Pesticide, Food and Envirnomental Implications, pp. 61-77.

Miskiewicz AG and PJ Gibbs, 1994. Organochlorine pesticides and hexachorobenzene in tissues of fish and invertebrates caught near a sewage outfall. Environ. Pollut., 84: 269-277.

Thingran, VG, 1974. Fisheries in India in the context of aquatic pollution. International Journal of Ecology and Environmental Science, 1: 15-18.

Dutta HM, 1996. A composite approach for evaluation of the effects of pesticides on fish. In Fish morphology, J.S.D. Munshi and H.M. Dutta, editors. Lebanon, Science Publisher Inc., pp. 249-254.

Ayoola SO and EK Ajani, 2008. Histopathological Effects of Cypermethrin on Juvenile African Catfish (Clarias gariepinus). World J. Biol. Res., 1(2). 
Monir MS, M Ashaf-Ud-Doulah, MK Rahman, JN Akhter and MR Hossain, 2015. Effect of cypermethrin on the histoarchitecture of gills and liver of a freshwater catfish, Pangasianodon hypophthalmus. Asian J. Med. Biol. Res., 1: 641-64.

Olufayo MO and $\mathrm{OH}$ Alade, 2012. Acute toxicity and histological changes in gills, liver and kidney of catfish, Heterobranchus bidorsalis exposed to cypermethrin concentration. Afr. J. Agric. Res., 7: 4453-4459.

Indirabai WPS, GG Tharani and P Seetha, 2010. Impact of sub-lethal concentration of endosulfan on biochemicals and histology of organ tissues of freshwater fish, Labeo rohita (hamilton, 1822). The Bioscan, 5: $215-218$.

Mostakim, GM, MM Mishu, MK Rahman and MS Islam, 2014. Chronic toxicity of organophosphorous pesticide Quinalphos 25EC and its effects on the morphological alterations in the kidney and livers of Silver barb (Barbonymus gonionotus). Proceedings of 5th International Conference on Environmental Aspects of Bangladesh [ICEAB 2014].

Nannu MTA, 2014. Effects of kinalux, an organophosphorus pesticide on the hematological parameters and some organs of nile tilapia (Oreochromis niloticus), MS thesis, Department of Fisheries Bilogy and Genetics, Bangladesh Agricultural University, Mymensingh, Bangladesh.

Prashanth MS, 2011. Environmental sciences histopathological changes observed in the kidney of freshwater fish, cirrhinus mrigala (hamilton) exposed to cypermethrin. Recent Research in Science and Technology, 3: 59-65.

Butchiram MS, KS Tilak and PW Raju, 2009. Studies on histopathological changes in the gill, liver and kidney of Channa punctatus (Bloch) exposed to Alachlor. J. Environ. Biol., 30: 303-306. 